\title{
IV Міжнародна науково-практична конференція «Заповідники Криму. Біорізноманіття і охорона природи в Азово-Чорноморському регіоні»
}

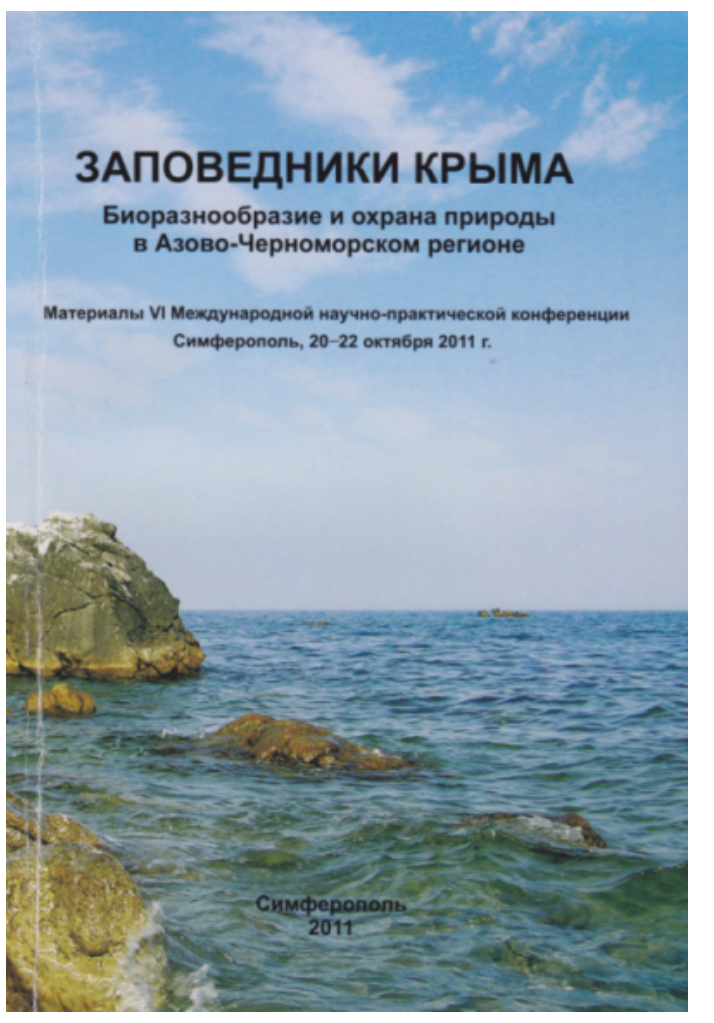

Конференція відбулася 20-22 жовтня 2011 р. в м. Сімферополі на базі Таврійського національного університету ім. B.I.Вернадського (ТНУ). Серед організаторів, крім ТНУ - Республіканський комітет АР Крим 3 охорони навколишнього середовища, Кримський науковий центр НАН України і МОН України, Кримська республіканська асоціація «Екологія i світ», Асоціація підтримки біологічного i ландшафтного різноманіття Криму «Гурзуф-97» та Державне підприємство «Науковий центр заповідної справи» Мінекології і природних ресурсів України. В Оргкомітет конференції увійшли 17 осіб 3 числа викладачів університетів, працівників Мінприроди та екологічних громадських організацій. 3 привітаннями та побажаннями плідної роботи конференції до учасників звернулися Голова Рескомприроди Е.Г.Бубнов, проректор 3 науки ТНУ В.Ф.Шульгін та декан географічного

факультету ТНУ Б.О.Вахрушев.

На пленарному засіданні були зачитані важливі доповіді стосовно проблем заповідної справи: А.І.Дуліцький - „Аксиоматизація заповідної справи: ще дві аксіоми”; Калениченко А.В. - „Міжнародний семінар з управління охоронюваними природними територіями (Монтана, США) як платформа для міжнародного співробітництва у сфері охорони природи”; Я.П.Дідух - „Завдання заповідників у вивченні динаміки екосистем під впливом глобальної зміни клімату"; Г.А.Прокопов „Червона книга Криму, сучасні передумови створення”; Личак O.I., Рудик O.М., Артов А.М. - „Проблеми і перспективи розвитку заповідної справи в Криму”. Дві останні доповіді були анонсами до подальшого обговорення піднятих проблем за круглим столом.

Працювали кілька секцій. Секція 1 - „Загальні питання охорони природи” (співголови Личак O.I. та Боков В.О.) проводила засідання в конференц-залі корпусу Б ТНУ. Секція 2 - „Питання охорони флори і фітоценозів” (голова Сна А.В.) та секція 3 „Питання охорони фауни і зооценозів” (співголови Дуліцький А.І., Гольдін П.С.) працювали в Кримському науковому центрі, що розташований у Ботанічному саду ТНУ. Усі заслухані доповіді відзначалися актуальністю, високим рівнем професіоналізму та вболіванням за справу охорони природи.

Після секційних доповідей та обговорення стендових доповідей відбулося обговорення за круглими столами - «Червона книга Криму» (керівники Єна А.В., Прокопов Г.А., Фатерига О.В.) та «Теорія заповідної справи і тенденції розвитку заповідної справи в Криму» (керівники Дуліцький А.І.. Личак О.І.). Ці засідання відзначилися гострою полемікою, особливо щодо принципів створення Червоної книги Криму та проблем фінансування iї друку. Пропонувалося взяти за зразок Червону книгу Донецької області, яка щойно вийшла 3 друку, але 3 певними змінами відповідно до 
особливостей природи Криму та системи місцевої організації природоохоронної діяльності.

Під час проведення виїзного семінару (керівник Прокопов Г.А.) до Регіонального ландшафтного парку «Тиха бухта» учасники спільно з адміністрацією парку безпосередньо на місці обговорили проблеми управління заповідною територією, питання охорони, рекреації, наукової діяльності, фінансування та ін.

Треба відзначити, що до початку семінару був якісно видрукуваний збірник матеріалів конференції, де крім тексту вказано місце роботи авторів та їх електронна пошта, що особливо важливо для підтримки контактів між авторами Червоної книги.

Шляхом обміну думками та внесеними пропозиціями учасників конференції було запропоновано прийняти резолюцію конференції, яку ми наводимо без будь-яких змін.

М.Ф. Бойко, А.В. Єна, Н.В. Загороднюк

\section{РЕЗОЛЮЦИЯ}

VI Международной научно-практической конференции «Заповедники Крыма - 2011. Биоразнообразие и охрана природы в АзовоЧерноморском регионе», 20-22 октября 2011 года, Симферополь, Крым

В Конференции приняли участие более 150 человек из 30 городов Украины, России, Республики Беларусь и Грузии, из 45 учреждений и организаций: в том числе из 12 заповедников и национальных парков, 5 ботанических садов, 21 университетов и институтов, 7 общественных природоохранных организаций. На конференции было заслушано 60 докладов, в сборнике материалов конференции опубликованы 85 научных статей 120 авторов.

В ходе проведения пленарного заседания, посвященного обсуждению наиболее актуальных вопросов охраны природы (природно-заповедный фонд в условиях глобальных климатических изменений, перспективы развития природно-заповедного фонда, судьба степей, эффективность природоохранного менеджмента и др.), трех секционных заседаний по общим вопросам заповедного дела, по проблемам охраны флоры и фауны Черноморского региона, а также 2 круглых столов «Красная книга Крыма» и «Теория заповедного дела и тенденции развития заповедного дела в Крыму» были высказаны и обсуждены предложения, послужившие основой для принятия данной резолюции.

Участниками Конференции отмечено, что за период, прошедший со времени проведения предыдущей $\mathrm{V}$ Международной научно-практической конференции «Заповедники Крыма - 2009. Теория, практика и перспективы заповедного дела в Черноморском регионе» (Симферополь, 22-23 октября 2009 г.), произошли события, которые можно расценивать как определенные успехи в охране природы Крыма. Они достигнуты благодаря совместным усилиям природоохранных учреждений, ученых и общественных организаций АРК. К этим успехам можно отнести:

- Создание регионального ландшафтного парка (РЛП) «Воздухоплавательный комплекс Узун-Сырт, гора Клементьева» площадью 840 га (постановление Верховной Рады АРК от 22.09.2010 г. № 1883-5/10); ландшафтных заказников местного значения «Караби-Яйла» $(2829,0$ га) и «Ай-Петринская яйла» (1795,0 га) (постановление Верховной Рады АРК от 22.12.2010 г. № 126-6/10);

На 01.01.2011 г. процент заповедности в АРК достиг 5,6\%, здесь насчитывается 156 территорий и объектов ПЗФ общей площадью 150820,9 га. С 1997 года (семинар в Гурзуфе) площадь ПЗФ в АРК выросла на 32 \%, количество объектов на $15,5 \%$. На территории Севастопольского горсовета при высоком проценте 
заповедности (30,3\%) за 1997-2010 годы создан лишь 1 объект (в 1998 году общезоологический заказник «Бухта Казачья», 23,2 га);

- $\quad$ При финансировании Фонда АРК по охране окружающей среды в рамках Региональной программы формирования национальной экологической сети в АРК были выполнены научные обоснования создания новых объектов ПЗФ: ландшафтных заказников «Караби» и «Ай-Петринская яйла», а также научные обоснования границ более 15 объектов ПЗФ местного значения: геологические памятники природы «Природные сфинксы в долине р. Чурук-Су», «Пещера-грот Данильча-Коба», «Змеиная пещера», «Пещера-грот Киик-Коба», «Карстовая шахта Максимовича», «Пещера МАН», заповедные урочища «Долина реки Сатера» и «Яйла Чатырдага», ботанические заказники «Урочище Парагельмен» и «Кастель», комплексные памятники природы «Гора-отторженец Парагильмен» и «Роща можжевельника высокого в районе Семидворья», региональные ландшафтные парки «Лисья бухта - Эчки-Даг» и «Воздухоплавательный комплекс Узун-Сырт, гора Клементьева» и др.;

- По инициативе Крымской республиканской ассоциации «Экология и мир» и Ассоциации поддержки биологического и ландшафтного разнообразия Крыма Гурзуф-97, при поддержке Рескомприроды АРК на базе Карадагского природного заповедника НАН Украины 26-28 ноября 2010 г. был проведен рабочий семинар «Заповедное дело в Крыму - 2010: Оценка состояния биоразнообразия и разработка проекта локальной экологической сети Восточного Крыма», материалы которого готовятся к изданию;

- Развернута и выполняется инициированная Киевским эколого-культурным центром и Госслужбой заповедного дела Минприроды Украины программа по выявлению и сохранению вековых деревьев Украины. Исследования, предпринятые в рамках этой программы в Крыму, позволили выявить 220 выдающихся деревьев (из 500 по всей Украине), возраст 32-х из них по оценкам превышает 1000 лет. В результате был составлен список из 15 деревьев, предложенных для заповедания в Крыму в 2011 году;

- В 2010 году по инициативе сотрудников природного заповедника «Мыс Мартьян», Никитского ботанического сада - Национального научного центра организовано первое в Крыму научное периодическое издание природно-заповедного учреждения - Научные записки природного заповедника «Мыс Мартьян»;

- В последнее время на территории Крыма начал реализоваться ряд программ по охране и восстановлению степей - проект Украинского общества охраны птиц «Усиленные экономические и правовые инструменты для сохранения степного биоразнообразия, адаптации к изменениям климата и их смягчение (Степное биоразнообразие)», проект Национального экологического центра Украины «Сохраним украинские степи!».

Одновременно участники конференции констатировали усиление антропогенного пресса на природные экосистемы Крыма. В результате действий различных бизнес-структур продолжается прямое уничтожение уникальных природных уголков Крыма, в частности, на Караньском плато, на плато Ай-Петри, в Лисьей бухте и множестве других прибрежных участков Черного и Азовского морей. Особую тревогу вызывает то, что эти действия происходят при попустительстве, а иногда и при прямом участии местных властей.

Участники конференции пришли к заключению о недопустимости:

- Отчуждения или самозахвата земель заповедных территорий;

- каких-либо попыток трансформации природных заповедников Крыма и Украины в биосферные заповедники и национальные парки, что чревато возможностью для перезонирования и выведения из-под охраны ценных природных территорий; 
- застройки побережий на участках с сохранившейся природной растительностью: такая застройка противоречит действующему законодательству, наносит непоправимый ущерб природе (в первую очередь, уязвимым экосистемам песчаных побережий);

- насаждения лесных массивов на территориях равнинного Крыма, имеющих уникальную степную растительность, в том числе на территориях, выведенных из хозяйственного использования, и потенциально пригодных для создания объектов ПЗФ, а также террасирования и посадки деревьев на яйлинских плато и степных склонах Крымских гор;

- промедления с разработкой и утверждением региональной Красной книги растений и животных АР Крым;

- отсутствия государственной политики по развитию заповедного дела в Украине: расформирована Государственная служба заповедного дела, сделана попытка отменить закон Украины по формированию национальной экосети Украины до 2015 года, невыполнение Указа президента Украины о создании национального природного парка «Волшебная Гавань» на Тарханкуте и других национальных парков в Украине, крайне низкое финансирование природных заповедников и др.;

- игнорирования морских акваторий при организации новых объектов ПЗФ (при создании НПП «Волшебная гавань» на Тарханкуте существующие охраняемые морские акватории вообще не были включены);

- введения в состав штатных сотрудников учреждений ПЗФ Крыма и Украины лиц, которые не имеют соответствующего профессионального образования.

Консолидированное мнение участников конференции в отношении перспектив и первоочередных задач заповедного дела в Черноморском регионе, включая Крым, сформулировано в виде следующих положений:

1. В результате обсуждения на круглом столе основных принципов заповедного дела, современного состояния системы ПЗФ Украины, обозначилась необходимость: а) разработки и утверждения концепции развития заповедного дела в Украине и Крыму, б) создания специальной Рабочей группы из числа сотрудников Минприроды Украины, Рескомприроды АРК и научных работников для разработки соответствующих положений и плана по их реализации.

2. В свете предыдущего положения, представляется актуальной четкое формулирование аксиом заповедного дела с привлечением к этой работе авторов соответствующих публикаций (например, В.Е. Борейко, А.И. Дулицкий, С.П. Иванов и др.).

3. Рекомендовать Рескомприроды АРК и Госуправлению охраны окружающей природной среды в г. Севастополе организовать выездные семинары среди местного населения и местных органов власти о важности и значении объектов ПЗФ и элементов экологической сети с привлечением ученых, преподавателей биологического и географического факультетов ТНУ в регионах, где вопросы заповедания территорий стоят особенно остро.

4. Рекомендовать Рескомприроды АРК усилить научно-исследовательские работы на территориях и объектах ПЗФ, зарезервированных для заповедания, на территориях региональной экосети, организовать систему мониторинга объектов ПЗФ Крыма.

5. Рекомендовать Рескомприроды АРК начать подготовку к изданию кадастра заповедных и перспективных для заповедания объектов Крыма с краткими описаниями и картосхемами.

6. Рассмотреть на государственном и региональном уровне вопрос о необходимости расширения границ целого ряда региональных ландшафтных парков и других 
объектов ПЗФ, в том числе путем выкупа распаеванных земельных участков (например, Караларский, Бахчисарайский РЛП и др.)

7. Обратиться в Министерства обороны Украины и России с просьбой рассмотреть вопрос о передаче земель под их заповедование (Опук, Школьное, Перевальное, высоты Кая-Баш («Караньский») и др.). Обратиться в Российско-Украинскую межгосударственную комиссию по вопросам пребывания Черноморского флота Российской Федерации с просьбой, чтобы в ходе инвентаризации земель, арендуемых Черноморским флотом РФ, определить их природоохранную значимость с перспективой включения особо ценных территорий в региональную экологическую сеть АР Крым и г. Севастополя и создания объектов ПЗФ (в первую очередь, заказника «Караньский»).

8. Рекомендовать Рескомприроды АРК ускорить процедуры по вынесению в натуру границ территорий и объектов ПЗФ, по решению проблем региональных ландшафтных парков (РЛП «Калиновский», «Караларский», «Лисья бухта» и др.) и Ялтинского ГЛПЗ. Госуправлению охраны окружающей природной среды в г. Севастополе - ускорить работы по вынесению в натуру границ заказников общегосударственного значения «Мыс Айя» и «Байдарский» - из-за их отсутствия существует угроза рекреационной застройки заповедных территорий и их буферных зон.

9. Обратить внимание Рескомприроды АРК на приоритетность заповедания степных биоценозов Крыма вдоль морских побережий, на Тарханкутском и Керченском полуострове, на южных склонах куэст, обладающих уникальной растительностью.

10. Продолжить работу над формированием Красной книги Крыма (ККК). Предложить Рескомприроды АРК изыскать средства на проведение мероприятий, связанных с формированием и публикацией ККК. Обратиться в Госуправление охраны окружающей природной среды в г. Севастополе с просьбой активизировать работы по изменению и дополнению Регионального красного перечня («Перечень редких и находящихся под угрозой исчезновения видов растений, не занесенных в Красную Книгу Украины, которые подлежат особой охране в границах территориально-административного образования г. Севастополя» (2003 г.)).

11. В связи с предыдущим положением, сформировать организационный комитет из числа крымских ученых, ответственных за формирование списков видов, рекомендуемых для включения в ККК: Ена А.В., Епихин Д.В., Фатерыга А.В., Бескаравайный М.М., Дулицкий А.И. Результатом работы должны стать списки видов, рекомендуемых к включению в ККК, и подготовка решения об их утверждении в Верховной Раде АРК.

12. Создать в Рескомприроды АРК и Госуправлении охраны окружающей природной среды в г. Севастополе Координационные советы по разработке и внедрению в практику планов действий по охране краснокнижных видов на территории АР Крым и г. Севастополь.

13. Обратиться к ученым, научным, образовательным и общественным организациям Крыма составить список природных территорий, объектов, находящихся под угрозой уничтожения и требующих срочного спасения («топ-десятку горячих точек Крыма») для привлечения внимания СМИ, властей, местного населения к этим проблемам и объектам. Презентацию приурочить к «экологическим» датам: 22 мая - Международный день биологического разнообразия; 5 июня Всемирный день охраны окружающей среды; 7 июля - День работника природнозаповедного дела.

14. Обратить внимание природоохранных органов на хаотичную застройку юговосточного и юго-западного (в границах г. Севастополя) побережий Крыма, 
которая приводит к уничтожению уникальных можжевелово-фисташковых редколесий и деградации прибрежных биоценозов вследствие попадания тонн снятого грунта в море.

15. Обратиться в Минприроды Украины с обоснованием экономической и экологической нецелесообразности создания искусственных лесных массивов на участках «неудобий» в исконно степных регионах, песчаных почвах в дельтах рек, почвах с близким залеганием грунтовых вод. Создать национальную программу по восстановлению степной растительности на залежных землях, выведенных из хозяйственного использования, а также на территориях выгоревших или погибших по иной причине искусственных лесонасаждений.

16. Обратиться в Рескомприроды АРК с обоснованием необходимости проведения обязательной экспертизы с участием независимых экспертов из числа специалистов научных организаций и вузов Крыма и Украины перед проектированием и проведением мероприятий по лесопосадкам в Крыму.

17. Предложить Рескомлесу АРК организовать рабочие встречи научных сотрудников с лесниками, другими работниками этого ведомства для обсуждения экологических вопросов ведения лесного хозяйства, лесовосстановления, формирования региональной и локальной экосети, повышения экологического образования.

18. Ученым Крыма активизировать усилия (создать рабочую группу) по изучению влияния на природные комплексы территорий ПЗФ санитарных рубок, регуляции численности диких животных, борьбы с «вредителями» леса, прокладки туристических маршрутов и других антропогенных воздействий на природные комплексы.

19. Обратиться в Севастопольский Горсовет и Горгосадминистрацию, Госуправление охраны окружающей природной среды в г. Севастополе, Министерство экологии и природных ресурсов Украины с предложением начать работу по созданию и утверждению Программы формирования экологической сети в г. Севастополе.

20. Объединить усилия, научных работников, общественных организаций и государственных учреждений для разработки государственной программы и принятия срочных мер по сохранению можжевельников на территории Крыма. Добиться полного запрета продажи изделий из можжевельника.

21. Признать необходимость регулярного централизованного издания научных трудов по заповедному делу, Летописей природы заповедников, выпускать компактдиски с этими материалами.

22. Создать рабочую группу из специалистов заповедного дела для разработки единых требований к предоставляемой документации по заповедным объектам: научных обоснований, проектов землеустройства, обоснований границ, экологических троп и рекреационных объектов.

23. Создать реестр специалистов в области изучения и сохранения биологического и ландшафтного разнообразия Крыма с целью адресного привлечения их (при необходимости) для участия в создании, разработки проектов землеустройства и вынесения границ в натуру объектов ПЗФ.

24. Создать сайт «Заповедное дело в Крыму»: электронный банк данных об объектах ПЗФ, зарезервированных и приоритетных территориях, выполненных и готовящихся проектах, документации, библиографию научных работ по заповедному делу и объектах ПЗФ Крыма под патронатом Ассоциации поддержки сохранения биологического и ландшафтного разнообразия Крыма «Гурзуф-97».

25. Продолжить работу по формированию экосетей на местном уровне: разработки схем локальной экосети, режимов природопользования, создания новых объектов ПЗФ. 
26. Обеспечить доступность информации о планируемых и создаваемых объектах ПЗФ. На сайте Комитета по охране окружающей среды размещать соответствующую информацию. Сопровождать принятие решений по этим вопросам общественными слушаниями.

27. Разработать базовые положения выделения и охраны прибрежных аквальных комплексов (ПАК). Определить принципы выявления землепользователя и получателя охранных обязательств на акваторию.

28. В рамках сохранения биоразнообразия прибрежных аквальных комплексов, ходатайствовать перед Минприроды Украины об отмене всех квот и ограничений на вылов рапаны - инвазивного вида, наносящего вред аборигенным черноморским сообществам.

29. Участниками конференции поддержать обращения экологов Севастополя по созданию заказника «Караньский». Обращение от имени участников конференции разослать в местные органы власти Севастополя, Госуправление охраны окружающей природной среды в г. Севастополе и СМИ.

30. В 2012 г. исполняется 15 лет с момента проведения семинара по сохранению биоразнообразия в Гурзуфе, предлагаем подготовить материалы для издания монографии, посвященной успехам и проблемам сохранения биологического и ландшафтного разнообразия в Крыму за 15 лет. 